\title{
Türk Toplumunun Boş Zaman Aktivitelerine Katılım Durumu: Motivasyon ve Engeller
}

\author{
Güliz COȘKUN \\ Sakarya Uygulamalı Bilimler Üniversitesi \\ gulizc@subu.edu.tr \\ ORCID ID: 0000-0002-5200-6370
}

Araştırma Makalesi

DOI: $10.31592 /$ aeusbed.691148

Geliş Tarihi: 19.02.2020

Revize Tarihi: 16.12 .2020

Kabul Tarihi: 29.12.2020

\author{
Atuf Bilgisi \\ Coşkun, G. (2021). Türk toplumunun boş zaman aktivitelerine katılım durumu: Motivasyon ve engeller. Ahi \\ Evran Üniversitesi Sosyal Bilimler Enstitüsü Dergisi, 7(1), 50-64.
}

ÖZ

Son yıllarda Türklerin boş zaman aktivitelerine katılımının artmakta olduğu gözlemlenmiștir. Bununla birlikte, Türk toplumunda bașta kadınlar olmak üzere bazı bireyler halen boş zaman aktivitelerine katılımda içsel, kişilerarası ve yapısal engeller yaşamaktadırlar. Konu ile ilgili yapılan önceki çalışmalar öğrenci veya öğretmen gibi sadece belli gruplar arasında yapılmıştır. Araştırmanın amacı Türk toplumunun boş zaman engellerini ve boş zaman aktivitesine katılma motivasyonlarını rekreasyon işletme sahipleri ve çalışanların bakış açısından analiz etmektir. Bu amaçla araştırmada nitel araştırma yöntemlerinden biri olan örnek olay incelemesi kullanılmıștır. İstanbul, Sakarya ve Kocaeli’nde bulunan 28 rekreasyon ișletmesi ile yüz yüze mülakat yapılmıştır. Sonuçlar Türklerin her üç tür boş zaman engelini de yaşadığını ve kadınların erkelere nazaran bu engellerle daha fazla karşılaştı̆̆ını göstermiştir. En çok yaşanan engeller; ilgi eksikliği, kendine güven eksikliği, toplum baskısı, zaman ve maddi imkân yetersizliği olarak ortaya çıkarılmıştır. Çalıșma sonuçları aynı zamanda boş zaman aktivitelerine katılan Türklerin motivasyonlarının içsel ve dışsal olduğunu desteklemiștir.

Anahtar Kelimeler: Boş zaman engelleri, motivasyon, boş zaman aktivitelerine katılım, rekreasyon işletmeleri.

\section{Participation in Leisure Actitivies among Turkish Society: Motivation and Constraints}

\begin{abstract}
An increase in leisure activity participation among Turkish people has been observed recently. However, some people, especially women, still experience intrapersonal, interpersonal, and structural constraints to participate in leisure activities. Previous studies on leisure constraints focused only on certain populations like students or teachers. Therefore, the purpose of this study is to analyze leisure constraints and motivation to participate leisure activities among Turkish people from the perspectives of recreation facility owners and employees. For the purpose of the study case study approach, which is one of the qualitative research methods was used. Face to face interviews were conducted among 28 recreation facilities located in İstanbul, Sakarya and Kocaeli. Results showed that Turkish people experience all three types of constraints, and women experience these constraints more often than men. The most common constraints were lack of interest, low self-confidence, societal pressure, lack of time and money. Study results also supported that Turkish people who participate in leisure activities have both intrinsic and extrinsic motivation.
\end{abstract}

Keywords: Leisure constraints, motivation, leisure participation, recreation facilities.

\section{Giriş}

Türk toplumunda boş zaman aktivitelerine duyulan ilginin artışıyla beraber son yıllarda yeni rekreasyon ișletmeleri hizmete açılmıștır. Belediyelerin sportif faaliyetlere yönelik parklar düzenlemesi, devlete ait sanat ve mesleki eğitim merkezleri ve halk eğitimin cüzi ücretlerle halka fiziksel ve kültürel aktivite temelli ders imkanları sunması kamusal rekreasyon alanında da gelişmeler olduğunu göstermektedir. Türkiye İstatistik Kurumu (TUIK) tarafından 2018 yılında hazırlanan raporlara göre 2000 y1lından 2018 y1lına kadar tiyatro salonu sayıs1 \%600 oranında artarak 99'dan 718 'e çıkmasına rağmen, seyirci sayısı 2,5 milyondan 7,8 milyona çıkmakla birlikte artış oranı \%190 olarak gözlemlenmiştir (2018a). Opera ve bale salonu sayısı iki katına çıkmış olup seyirci sayısında gözlemlenen artış sadece yaklaşık \%45'dir (TUIKK, 2018b). Sinema salonu sayısı ise 6 katına çıkmış olup seyirci sayısı dört katına çıkmıştır (TUIK, 2018c). Bu raporlardan anlaşılacağı gibi sosyal ve kültürel aktivitelere katılımdaki artış, aktivite sayısındaki artış ile paralellik göstermemektedir. Spor kulübü sayıs1 2007'den 2014'e 8,593'ten 13,211'e yükselirken (\%53) (TUíK, 2014a), ayn1 y1llar arasında lisanslı sporcu sayısı ise 1,621,349'dan 3,219,324'e çıkmıştır (\%98) (TUİK, 2014b). Bu verilere göre profesyonel olarak spor yapan insanların sayısında bir artış olduğu görülmektedir. Diğer 
yandan rekreatif faaliyetlere katılım oranındaki değişim üzerine son yıllara ait istatistiksel veri bulunamamaktadir.

Sağlık Bakanlığının raporuna göre Türk toplumunda obezlik oranı erkeklerde \%20, kadınlarda $\% 41$, beş yaşın altındaki çocuklarda \% 8,5 iken 6 ila 18 yaş grubunda \%8,2'dir (Türkiye Cumhuriyeti Sağlık Bakanlı̆̆ı, 2010). Boş zamanlarında Türklerin daha sedanter aktiviteleri tercih etmeleri, özellikle gençlerin bilgisayar başında çok zaman harcamaları obezite oranının yüksek olmasının başlıca sebepleri olarak sayılabilir. Bu durumu değiştirmek için özellikle obezite oranının daha yüksek görüldügü kadınlara ve gençlere yönelik boş zamanlarını daha aktif bir şekilde değerlendirilmelerini sağlayacak programlar geliştirmek gerekmektedir.

Yakın zamanda Türkiye'de yapılan bir çalışma boş zaman engellerinin kişilerin yaşam doyumuna olumsuz etki ettiğini göstermiştir (Turan, Gülşen, ve Bilaloğlu, 2019). Diğer taraftan boş zaman aktivitelerine katılan insanların yaşamlarından aldığı tatmin daha yüksektir (Yerlisu, Ağyar, ve Bahadır, 2012). Bu sebeple bu engellerin mahiyetinin araştırılması, engelleri en az düzeye indirilerek daha mutlu bir toplum olma yolunda adım atma açısından gereklidir. Türkiye'de boş zaman davranışı ve engelleri üzerine yapılan çalışmaların büyük bir çoğunluğu nicel olmakla birlikte öğrenciler arasında uygulanmıştır. Ayrıca bu olguya sadece tüketici bakış açısından bakılmıştır. Bu çalışmanın literatürdeki bu açığın kapatılmasına katkı sağlayacağı dğşgnülmektedir. Dolayısıyla bu çalışmanın amacı Türk toplumundaki bireylerin boş zaman davranışlarının, boş zaman aktivitelerine katılma motivasyonlarının ve engellerinin rekreasyon işletmeleri bakış açısından değerlendirilmesidir.

\section{Kavramsal Çerçeve}

İnsanların boş zamanlarında fiziksel veya kültürel aktiviteye katılmasını engelleyen faktörleri belirlemek, bu faktörleri en aza indirip katılımı teşvik etmek açısından önemlidir. Crawford ve Godbey (1987) insanların boş vakit aktivitelerine katılımındaki başlıca engelleri içsel, kişilerarası ve yapısal olarak üç ana başlıkta incelemiştir. Boş zaman aktivitesine katılımdaki içsel engeller kişinin dış faktörlerden bağımsız olarak kendi psikolojisi ile alakalı engellerdir. Kişilerarası engeller ise insanlar arasındaki ilişkilerden kaynaklanan engellerdir. Buna örnek olarak futbol maçı yapmak isteyen birinin yeterince katılımı sağlayamamasından dolayı aktiviteye katılımının engellenmesi verilebilir. Yapısal engeller insanların aktiviteye katılım için uygun kıyafet bulamaması veya uygun mekâna erişim sağlayamamasıdır. Boş zaman engelleri teorinin ilk defa ortaya atıldığ yıllardan beri değişik ülkelerden birçok araştırmacının ilgisini çekmiştir. Boş zaman engelleri literatürde cinsiyet (Adam, Hiamey, ve Afenyo, 2015; Brown, 2001; Coble, Selin, ve Erickson 2003; Koca, Henderson, Aşçı ve Bulgu, 2009) ve motivasyon (Hubbard ve Mannell, 2001; Koçak, 2017b) gibi değişkelerle birlikte incelenmiştir.

\section{Boş Zaman Engelleri ve Cinsiyet}

Ulusal ve uluslararası alanda yapılan birçok araştırma boş zaman engellerini cinsiyet bakış açısından ele almıştır (Coble, Selin, ve Erickson, 2003; Fedler ve Ditton, 2001; Kara ve Özdeoğlu, 2017; Koca, Henderson, Asci, ve Bulgu, 2009). Araştırmaların sonucu gelişmiş ülkelerde bile kadınların erkeklere oranla daha fazla engelle karşılaştı̆̆ını göstermiştir. Amerika'da yapılan araştırmalar sonucunda kadınların parklara gitmekten erkeklere nazaran daha fazla çekindikleri görülmüştür (Coble vd., 2003). Başka bir araştırmada ise kadınların boş vakit aktivitesine devam etme konusunda erkeklerden daha fazla zorlandıkları ortaya çıkmıştır (Fedler ve Ditton, 2001). Gelişmişlik düzeyleri farklı olan Avustralya, Gana ve Brezilya'da yapılan araştırmalarda, kadınların boş zaman aktivitelerine katılamamalarındaki en önemli sebebin ailevi sorumlulukları erkeklerden daha fazla hissetmeleri olduğu ortaya çıkarılmıştır (Adam vd., 2015; Andrade, Junior, Capistrano, Beltrame, Pelegrini, Crawford, ve Gomes Felden, 2019; Brown, 2001).

Türkiye'de yapılan çalışmalarda ise kadınların boş zaman aktivitesine katılımında ailevi sorumlulukların yanı sıra dini ve sosyal engellere de rastlanmıştır (Koca vd., 2009). Yazarlara göre kadınların boş zaman engeli yaşamasındaki bir diğer faktör ise hayatlarındaki erkek figürleridir. 
Türkiye'de yapılan başka bir araştırma kadınların erkeklerden daha fazla yaşadığ 1 engelleri erişim, arkadaş eksikliği ve ilgi eksikliği olarak sıralamıştır (Kara ve Özdeoğlu, 2017). Kadınların bu engelleri hissetmeleri üzerlerindeki sosyal baskıdan kaynaklandığı çalışmada vurgulanmıştır. Benzer sonuçlar üniversite çalışanları arasında yapılan bir çalışmada ortaya çıkmıştır. Turan, Gülşen ve Bilaloğlu (2019) sadece kadın çalışanlar arasında yaptığı araştırmada, kadınların boş zaman aktivitesi yapmadaki engellerinin ilgi eksikliği ve birey psikolojisi olduğu saptanmıştır. Özetle değişik sosyal ve ekonomik statüdeki kadınlar boş zaman aktivitelerine katılmada benzer engeller yaşamaktadır.

Üniversite ve lise öğrencileri arasında yapılan çalışmalar kadınların yaşadığı engellerin yaştan bağımsız olduğunu ortaya koymuştur. Üniversitede okuyan kız öğrencilerin rafting ve bisiklet aktivitelerine katılımlarında içsel ve kişilerarası engelleri erkeklerden daha çok deneyimledikleri görülmüştür (Albayrak, Caber, ve Crawford, 2007). Kız öğrenciler bu engelleri sadece sportif faaliyetlerde değil, kültür, sanat ve doğa etkinlikleri ve turistik etkinliklere katılımda da hissetmektedirler (Ekinci, Kalkavan, Üstün, ve Gündüz, 2014). Diğer bir araştırmada kız öğrencilerin deneyimlediği başlıca boş zaman engelleri sorumluluklar, beklentiler ve yaşam tatmini, ırk, sosyal politikalar ve toplumda kadın ve erkeğin statüsü olarak listelenmiştir (Demir, 2005). Bu bağlamda üniversitede okuyan kız ögrencilerin erkeklere nazaran daha az sportif faaliyet çeşidine katılmaları beklenen bir sonuçtur (Demir, 2003). Lise öğrencileri arasında da benzer bulgulara rastlanmıştır (Ayhan, Ekinci, Yalçın, ve Yiğit, 2018). Kız öğrencilerin rekreasyon aktivitelerine katılmamalarının bir diğer sebebi de bu konuda daha az bilgi sahibi olmalarıdır (Özşaker, 2012). Türk toplumunda kadınların çocukluklarından itibaren dışarıda oynamaya teşvik edilmemeleri rekreasyon aktiviteleri konusundaki ilgi eksikliğinin sebebi olarak gösterilebilir. Çetinkaya, Yıldız ve Özçelik (2018) yaptığ1 çalışmada kadınlar milli parkları ziyaretlerine engel olarak bu konuda erkekler kadar bilgi sahibi olmamalarını belirtmişlerdir. Boş zaman engellerine cinsiyet bakış açısından bakan çalışmaları özetleyecek olursak Türkiye'de değişik yaş gruplarındaki kadınların boş zaman aktivitelerine katılımlarının kısıtlı olmasının sebepleri olarak erkeklere nazaran ailelerine karşı daha fazla sorumluluk sahibi olmaları ve daha fazla toplumsal baskı hissetmeleri sıralanabilir. Boş zaman engelleri ve cinsiyet arasındaki ilişkiyi irdeleyen çalışmalarda dünya genelinde benzer sonuçlar elde edilmiş olması, kadınların boş zaman aktivitelerine katılım konusunda yaşadığ 1 sıkıntıların evrensel olduğunu göstermiştir. Türkiye'de yaşayan kadınların yaşadığı boş zaman engellerini incelemek, bu engellerin azaltılması ve kadınların boş zaman aktivitelerine teşvik edilmesi açısından gereklidir.

\section{Türk Toplumunda Boş Zaman Aktivitelerine Katılım ve Engeller}

Yapılandırılmış boş vakit aktivitesi Türk toplumunda gelişmiş ülkelerde olduğu kadar yaygın değildir. Türkler arasındaki en yaygın boş zaman aktivitesinin televizyon izlemek gibi evde yapılan aktiviteler olduğu bazı çalışmalarca desteklenmiştir (Ekinci, Kalkava, Üstün, ve Gündüz, 2014; Erkip, 2009; Gürbüz ve Henderson, 2014; Hacioglu, Avcikurt, Ilban, ve Sapar 2005). Üniversite öğrencileri arasında tercih edilen en yaygın boş zaman aktivitelerinden evde olanlar birinci sırada yer alırken bunu takiben spor, sosyal aktivite, kültürel aktivite, eğitici aktivite, açı alan rekreasyonu ve turizm gelmektedir (Gürbüz ve Henderson, 2014).

Türkiye'de boş zaman engelleri üzerine yapılan çalışmaların çoğunluğu öğrenciler arasında uygulanmıştır. Öğrencilerin karşılaştığı boş zaman engelleri arasında tesis eksikliği, para sorunu gibi yapısal engeller birinci sırada yer almaktadır (Gürbüz ve Henderson, 2014). Başka bir çalışmada ise öğrencilerin içsel ve kişilerarası engelleri yapısal engellere nazaran daha fazla yaşadığı tespit edilmiştir. Bahsi geçen çalışmada ilgi eksikliği birinci sırada yer alırken bunu takiben sosyal ortam eksikliği ve arkadaş eksikliği gelmektedir. Tesis eksikliği ve zaman gibi yapısal engeller ise en son sırada yer almaktadır (Demirel ve Harmandar, 2009). Öğrencilerin karşılaştığı engellerin ciddiyeti bulundukları bölge veya şehre göre değişebilmektedir. Ülke çapında yapılan bir araştırmada doğu bölgelerde yaşayan öğrencilerin daha fazla engelle karşılaştıkları ortaya çıkmıştır (Ayhan vd., 2018). Yapılan boş zaman aktivitesinin içeriği de göz önünde bulundurulması gereken unsurlardan biridir. Örneğin bisiklet ve rafting gibi beceri gerektiren aktivitelere katılımda daha önceden deneyim sahibi olmanın olumlu etkisi olduğu gözlemlenmiştir (Albayrak vd., 2007). Gelir düzeyi öğrencilerin katılımını etkileyen önemli faktörlerden biridir (Ekinci vd., 2014; Özşaker, 2012). Üniversite 
öğrencileri arasında yapılan çalışmaların sonucunda üniversitelerin öğrencilere boş zaman aktivitesi yapmaları için sundukları imkânların yetersiz olduğu söylenebilir.

Spor salonu üyeleri arasında yapılan bir çalışmada fiziksel aktivitelere katılımdaki başlıca engellerin içsel olduğu ortaya çıkmıştır (Koçak, 2017a). Spor salonuna giden insanların kişilerarası ve yapısal engellerle karşılaşmaması beklenen bir durumdur. Engellerin daha iyi anlaşılabilmesi için boş zaman aktivitesi yapmayan kişilerin davranışları incelenmesi gereklidir. Boş zaman aktivitesi yapanlar ve yapmayanların karşılaştırıldığı bir çalışmada boş zaman aktivitesine katılımdaki engellerin uygun arkadaş bulamama ve ilgi eksikliği olarak ortaya çıkmıştır (Kara ve Özdeoğlu, 2017). Ayrıca gelir seviyesi düşük olan insanların boş zaman aktivitelerine erişimlerinin kısıtlı olması çalışmanın sonuçlarından biridir. Öğretmenler arasında yapılan bir çalışmada ise boş zaman aktivitelerine katılımdaki en büyük engelin yeterli zaman bulunamaması olduğu gözlemlenmiştir (Üstün, Ersoy, ve Bişgin, 2017). Aynı çalışmada boş zamanlarında fiziksel aktivite yapmayı tercih eden öğretmenlerin diğer aktiviteleri tercih edenlere göre daha az engelle karşılaştığı tespit edilmiştir. Milli parkları ziyaret etmek yaygın bir boş vakit aktivitesi olmasına rağmen bu konuda Türkiye'de yapılan araştırmalar kısıtlı sayıdadır. Çetinkaya vd. (2018) Antalya'da yaşayanlar arasında yaptığı çalışma bunlardan biridir. Bu çalışma sonucunda Türklerin milli parkları ziyaret etmede yaşadıkları başlıca engellerin bilgi ve tesis eksikliği, ulaşım ve para sorunu olduğu tespit edilmiştir. Buna ek olarak evli olanların bekâr olanlara göre, 65 yaş üzerindekilerin gençlere göre ve eğitim düzeyi düşük olan kişilerin yüksek olanlara göre daha fazla engelle karşılaşı ı̆ı aynı çalışmanın diğer bulgularındandır. Sonuç olarak Türkiye'de yaşayan bireyler yaptıkları aktiviteye, yaşadıkları yere veya gelir düzeylerine bağlı olarak içsel, kişilerarası ve yapısal engelleri deneyimlemektedir.

\section{Boş Zaman Aktivitelerine Katılım ve Motivasyon}

Boş zaman engelleri insanların boş vakitlerinde bir aktiviteye katılmalarına her zaman mani olmamaktadır. Bazı araştırmalara göre insanların motivasyonu yeterince yüksek ise engelleri boş zamanlarında rekreatif faaliyetlere katılabilirlerö bu süreci yazarlar 'engellerle pazarlık etme' olarak adlandırmışlardır(Hubbard ve Mannell, 2001). Boş zaman engellerinin pazarlık edilerek aşıldığı Türkiye'de yapılan bir çalışmada da desteklenmiştir (Koçak, 2017b). Bu sebeple boş zaman engellerini araştırırken motivasyon faktörünü de ele almak gerekir. Motivasyonun engeller ve boş vakit aktivitesi katılımı üzerindeki etkileri bazı araştırmalarda gözlemlenmiştir (Alexandris, Tsorbatzoudis, ve Grouios, 2002; Crompton ve Kim, 2004). Bu çalıșmalar motivasyonu yüksek olan bireylerin boş zaman engelleri ile daha kolay başa çıkabildiklerini göstermiştir. Türkiye'de yapılan bir çalışmada ise motivasyonun sportif faaliyetlere katılımda olumlu etkisi olmakla beraber, sanat ve kültürel faaliyetlere katılımda herhangi bir etkisine rastlanmamıştır (Yerlisu vd., 2012). Sportif faaliyetlerin sanat ve kültürel faaliyetlere göre daha aktif bir katılım gerektirdiği göze alındığında bu sonuç şaşırtıcı değildir.

Boş zaman engellerinin cinsiyet ve motivasyon ile ilişkisini inceleyen çalışmalar genel olarak katılımcıların bakış açısından ele alınmıştır. Sonuçlar kadınların daha fala engelle karşılaştığını ve motivasyonu yüksek olan bireylerin engelleri aşmakta daha yetkin olduklarını göstermektedir. Konunun rekreasyon işletmesi sahipleri ve çalışanlarının bakış açısından incelenmesi, literatüre daha geniş bir bakış açısıkazandıracaktır. Ayrıca elde edilen sonuçlar bu sektörde çalışanlara daha somut öneriler sunulmasına imkân sağlayacaktır.

\section{Yöntem}

\section{Araştırma Modeli}

$\mathrm{Bu}$ çalışmada nitel bir araştırma yöntemi olan örnek olay incelemesi uygulanmıştır. Örnek olay incelemesi bir olayın derinlemesine ve detaylı bir biçimde incelenmesine olanak sağlamaktadır (Creswell, 2007). Çalışmada Marmara bölgesinde bulunan rekreasyon işletmeleri seçilmiştir. 


\section{Evren ve Örneklem}

Görüşmeler Aralık 2018 ayında yapılmıştır. İstanbul, Kocaeli ve Sakarya'da bulunan 28 rekreasyon işletmesi sahibi ve çalışanı ile 30 ile 90 dakika arasında mülakat yapılmıştır. Çalışmaya dahil edilecek rekreasyon işletmelerinde bulunduğu bölgedeki yerel halka gelişim, eğlence ve dinlence imkanı sunuyor olma şartı aranmıştır. Çalışmaya katılan işletmeler arasında 8 spor salonu, 5 otel spa (merkezi, 4 spor kulübü, 3 sanat merkezi, 3 Sivil Toplum Kuruluşu (STK), 1 sinema salonu, 1 binicilik kulübü, 1 yoga salonu, 1 etkinlik şirketi ve 1 açık alan rekreasyon merkezi bulunmaktadır.

\section{Veri Toplama Araçları}

Yüz yüze görüşme tekniği ile yapılandırılmış mülakat uygulanmıştır. İlk olarak işletmecilerin bilgi düzeyini ölçme açısından 'Sizce leisure nedir?' sorusu yöneltilmiştir. 'Leisure' kelimesinin tam olarak Türkçe karşılığ 1 olmadığ 1 için özellikle İngilizcesi kullanılmıştır. İşletmecinin anlamaması durumunda açıklama yapılmıştır. Diğer sorular işletmeye gelenlerin demografik özellikleri, gelme sıklıkları, gelmelerini etkileyen faktörler, Türk kültüründe boş zaman aktivitesinin yeri, boş zaman engelleri ve motivasyon konularını içermektedir. İşletmelere sorulan sorulardan bazıları 'Faaliyetlerinize katılanların kadın erkek yüzdesi nedir?', 'Faaliyetlerinize düzenli katılımı etkileyen faktörler nelerdir?', 'Türk toplumunun rekreasyona bakış açısı nedir?, 'Faaliyetlerinize katılanların motivasyonları nelerdir?','Faaliyetlerinize katılımı engelleyen faktörler nelerdir?' ve 'Faaliyetlerinize katılımda kadınların yaşadığı engeller nelerdir?' Sorular röportaj yapılan işletmeye göre farklılık göstermektedir. Örneğin spor salonu gibi üyelik gerektiren işletmelerle yapılan mülakatlarda üyelikler hakkındaki sorulara daha fazla yer verilmiştir. Diğer yandan etkinlik şirketi gibi üyelik gerektirmeyen işletmelere müşterilerin katılım sıklığı hakkında sorular yöneltilmiştir.

\section{Verilerin Toplanması ve Analizi}

Elde edilen veriler üzerinde içerik analizi uygulanmıştır. Verilerin analizinde boş zaman engelleri (Crawford ve Godbey, 1987) ve motivasyon (Hubbard ve Mannell, 2001) konusunda daha önce yapılan çalışmalar dikkate alınmıştır. Daha önce bu konuda yapılan çalışmalardaki bulgular bu çalışmada elde edilen bulgularla karşıllaştırılmıştır. Karşılaştırmada engeller üç ana grupta incelenmiştir: içsel, kişilerarası ve yapısal. Motivasyon ise iç motivasyon ve dış motivasyon olarak iki ana grupta incelenmiştir. Buna ek olarak boş zaman engellerinin cinsiyet ile iliş̧kisi irdelenmiştir.

\section{Araştırma Etiği}

Bu çalışmanın verileri 2018 yılı Aralık ayında toplandığı için etik kurul onayı kapsamına girmemektedir.

\section{Bulgular}

İşletmecilerden alınan bilgilere göre boş zamanlarında spa merkezlerine gidenlerin ve açık alan rekreatif faaliyetlere katılanların eğitim ve gelir seviyelerinin diğerlerine nazaran daha yüksek olduğu ortaya çıkmıştır. Diğer yandan ücretsiz hizmet veren STK'ların aktivitelerine gönüllü olarak katılanların gelir seviyelerinin düşük olduğu gözlemlenmiştir. Yaş aralıklarına baktığımızda STK haricindeki işletmelere devam edenlerin 40 yaşın altında olduğu, spor kulüplerine üye olanların ise çoğunlukla 18 yaş altında olduğu görülmüştür. Kadınlar sanatsal faaliyetlere ve gönüllü hizmetlere daha fazla ilgi duyarken, erkekler boş zamanlarında sinemaya gitmeyi tercih etmektedir.

Tablo 1

Boş zaman aktivitelerine katılanların demografik yapısı

\begin{tabular}{lllll}
\hline İşletme & Yaş Grubu & Ĕ̆itim Düzeyi & Gelir düzeyi & Cinsiyet \\
\hline Spa merkezi(Otel) & $20-40$ & Yüksek & Yüksek & Karışı \\
Spor Kulübü & 18 ve altı & Ortaokul-lise & Değişken & Genelde erkek \\
Spor/Yoga Salonu & $18-40$ & Lise ve üstü & Orta & Karışık
\end{tabular}




\begin{tabular}{lllll} 
Sanat Merkezi & $20-40$ & Yüksek & Orta & Genelde kadın \\
$\begin{array}{l}\text { Açık Alan } \\
\text { Rekreasyon/Binicilik }\end{array}$ & $\begin{array}{l}\text { Değişken/genelde } \\
\text { aileler }\end{array}$ & Yüksek & Yüksek & Karışık \\
STK & $6-70$ & Değişken & Düşük & Genelde kadın \\
Etkinlik Şirketi & $20-60$ & Yüksek & Orta & Genelde kadın \\
Sinema & $15-45$ & Değişken & Değişken & Genelde erkek \\
\hline
\end{tabular}

Tablo 1'de görüldüğü üzere yapılan aktiviteye göre katılımcıların demografik özellikleri değişiklik göstermektedir.

Ilk soru olan 'Sizce leisure nedir?' sorusuna cevap olarak en fazla 'boş zaman' cevabı verilmiştir. Daha sonrasında ise surayla 'iş ve sorumluluklarda arta kalan zaman', 'rekreasyon', 'eğlence', 'aile' ve 'dinlenme' cevapları alınmıştır. Alınan cevaplar çoğu işletmecinin 'leisure' kelimesinin tam anlamıyla idrak etmemiş olduğunu göstermektedir. Bazı işletmeciler 'leisure' ve rekreasyon kelimelerinin aynı şey olduğunu düşünürken, bazıları da yapılan aktivite olarak tanımlamıştır. Bu yanlış anlaşılmanın 'leisure' kelimesinin Türkçe'de tam karşılığ olmamasından kaynaklanması olasıdır. Bazı yazarlar 'leisure' konseptini ruh hali olarak tanımlamışlardır (Kelly ve Freysinger, 2000). Bu yaklaşıma Türk literatüründe yer verilmediği için insanlar bu konsepti ruh hali olarak değerlendirmemektedir. Katılımcılardan bir spor kulübü çalışanının 'Bizim boş zamanımız yok. Birçok idman programlarımız var. Sporcularımız çok meşgul.' ifadesinde de belirttiği gibi aslında 'leisure' boș zaman anlamına gelmemektedir. STK'da çalıșan bir katılımcının ifadesine göre boș zaman kavramı Türk kültüründe yer almamaktadır: 'Bir Müslümanın boş zamanı olmaz asla. Bu yabanclların kültürümüze yansittığı bir kelimedir. O yüzden boş zaman bizim kültürümüzü yansitan bir kelime değildir. Bunun altını çizmemiz gerek.' Türk toplumunda boş zaman aktivitelerinin batılı ülkeler kadar yaygın olmadığı açıktır. Fakat katılımcıların 'leisure' konseptini hiçbir şey yapmamak ile bağdaştırması tamamen çeviri ile alakalı bir problemdir. Bu konuda rekreasyon işletmesi sahiplerinin ve çalışanlarının bilinçlendirilmesi insanlara daha iyi hizmet vermelerine imkan sağlayacaktır.

Rekreasyon işletmesine gelenlerin üyelik ve katılım durumu işletmenin mahiyetine göre değişim göstermektedir. Otellerdeki spa merkezlerine gelenlerden uzun süre üye olanlar çok nadir olmakla birlikte, ortalama üye olma süresi bir yıldan azdır. Benzer şekilde, her spor salonunda bir yılı aşkın süre ile üye olan en az bir kişi bulunurken ortalama üye olma süresi 6 ay ila bir yıl arasında değişmektedir. Spor kulüplerine genelde genç yaştakiler sertifika almak veya profesyonel sporcu olmak içi devam ettikleri için üye olma süreleri birkaç yıldan 7-8 yıla kadar çıkabiliyor. Haftalık katılım sayısına baktığımızda otellerdeki spa merkezlerinde, yoga salonunda ve sanat merkezlerinde ortalama haftada bir veya iki iken, spor kulüpleri ve salonlarında bu sayı 4 ila 6 arasına çıkmaktadır. Bırakma sebeplerinden en sik bahsedilenler arasında zaman ve motivasyon eksikliği, ailevi sorumluluklar ve parasal sıkıntılar bulunmaktadır. Düzenli katılımı etkileyen faktörler ise spa merkezleri için indirimler, sağlık sorunları, spor salonları için grup dersleri, donanımlı spor hocaları, müşteri tatmini, servis kalitesi, kişisel gelişim, spor kulüpleri ve binicilik için lisans sistemi olarak sıralanmıştır. STK'lar ücretsiz hizmet sundukları için katılım konusunda katı kurallar uyguladıklarını belirtmişlerdir. Sanat merkezlerinde ise katılımcıların sıcak bir ortamda kaliteli zaman geçirmek ve öğrenme amaciyla geldikleri ortaya çıkmıştır. Sinema salonu işletmecisi ise salonun merkezi bir yerde bulunmasının katılımı sağlayan en önemli faktör olduğunu öne sürmüştür. Rekreasyon aktivitelerine katılımı etkileyen faktörler işletmecilerin bakış açısından değerlendirildiğinde devamı sağlayan unsurların kişiden kaynaklı değil, işletmenin tutumundan ve verilen hizmetten kaynaklı olduğu sonucuna varılmıştır. Üyelik ve katılım ile ilgili analizler Tablo 2'de özetlenmiştir.

Tablo 2

Boş Zaman Aktivitelerine Katılım

\begin{tabular}{llll}
\hline İşletme & $\begin{array}{l}\text { Haftalık } \\
\text { Katılım }\end{array}$ & Ortalama Üye Olma Süresi & Bırakma Sebepleri \\
\hline $\begin{array}{l}\text { Spa merkezi (Otel)/ } \\
\text { Yoga Salonu }\end{array}$ & $1-2$ & Bir yıldan az & $\begin{array}{l}\text { Zaman eksikliği, yoğunluk, ailevi } \\
\text { sorunlar, sağllk problemleri } \\
\text { Spor Kulübü }\end{array}$ \\
& $4-6$ & Bir yıldan fazla & $\begin{array}{l}\text { Yaralanma, iş bulma, şehir dişına } \\
\text { çkma, ders yoğunluğu, parasal }\end{array}$
\end{tabular}




\begin{tabular}{llll} 
Spor Salonu & $4-6$ & 6 ay ile bir yıl arası & $\begin{array}{l}\text { S1kıntılar } \\
\text { Motivasyon eksikliği, hedeflere } \\
\text { ulaşma, kendine güven yoksunluğu }\end{array}$ \\
$\begin{array}{l}\text { Sanat Merkezi } \\
\begin{array}{l}\text { Açı Alan } \\
\text { Rekreasyon/Binicilik }\end{array}\end{array}$ & $1-2$ & $\begin{array}{l}\text { Çocuklar 10, yetişkinler } 8 \text { ay } \\
\text { Farklı beklentiler }\end{array}$ \\
$\begin{array}{l}\text { STK } \\
\text { Sinema }\end{array}$ & 2 & $\begin{array}{l}\text { En ay } \\
-\end{array}$ & Kisıtlı zaman \\
\hline
\end{tabular}

Katılımcılara boş vakit aktivitelerinin Türk kültüründeki yerini sorduğumuzda alınan cevaplar literatürle k1smen örtüşmektedir (Ekinci vd., 2014; Erkip, 2009; Gürbüz ve Henderson, 2014; Hacıoğlu vd., 2005). Bazı işletmecilere göre Türk toplumunda bireyler boş vakitlerini alışveriş merkezlerinde ve kafelerde geçirmeyi tercih ediyorlar. 'Türk toplumu kafelerde, barlarda, oyun salonlarında ve alışveriş merkezlerinde boş boş gezerek zaman harcamaktadır. Yaptı̆ğ rekreasyon yazları deniz tatili, kışları avm'lerden öteye gitmemektedir. Telefon, tablet, Instagram, Tweet atmak sosyal mecrada binlerce takipçisi olmak ve gerçekliği olmayan sanal bir alemde olmayan bir hayat kurmak son ylllarda ki maalesef en büyük rekreasyon aktivitesi olmuştur. Özellikle gençlerimiz bu konuya kendini aşırı derecede kendini kaptırmıştır.' Gençlerin teknoloji bağımlılıklarının rekreasyon aktivitelerine katılımları üzerindeki negatif etkisi daha önceki çalışmalarla da desteklenmiştir (Eryılmaz ve Bal, 2019).

Diğer taraftan bazı işletme sahipleri bu konuda olumlu bir tutum sergilemektedir. Özellikle spor salonu işletmecilerinin belirttiğine göre son yıllarda Türk halk1 rekreasyon aktivitelerine daha fazla ilgi duymaya başlamış ve buna paralel olarak üye sayılarında gözle görülür bir artış olmuştur. Bir spor salonu işletmecisinin 'Türk toplumun rekreasyona bakışı değişti, eskiden kısa süreli sadece eğlence amaçll yapılırken bugünlerde daha çok kişisel gelişim aktivitelerine yöneliyorlar. Üye sayımız arttı.' ifadesinden anlaşılacağ 1 gibi Türk halkı son yıllarda boş vakitlerini gelişim amaçlı kullanmaya başlamıştır.

Boş zaman engelleri ile alakalı soruların cevapları analiz edildiğinde Türk toplumundaki bireylerin, her üç engeli de (içsel, kişilerarası ve yapısal) yaşadıkları ortaya çıkmıştır (Crawford ve Godbey, 1987). Türklerin daha sedentar, çaba gerektirmeyen aktiviteleri seçtikleri katılımcıların bir çoğu tarafından ifade edilmiştir. Bunun yanı sıra kendine güven ve motivasyon eksikliği ve bilinçsizlik insanların karşılaştığı başlıca boş zaman engelleri olarak sıralanmıştır. Bir yoga salonu sahibi bu konudaki görüşünü şu şekilde ifade etmiştir: 'Bence günümüzde rekreaktif faaliyetleri engelleyici en temel engel kişinin kendi bakış açısı ve bilinci. Tercihleri rekreatif bir çalışmaya katılmaktansa kafelerde çay sigara tüketmek oluyor.' Ayrıca Türk halkının rekreasyon aktivitesinin ne olduğunu bilmediği veya farkında olmadığı da işletmeciler tarafından ifade edilmiştir. İçsel engellerin rekreasyon aktivitelerine katılım üzerindeki etkisi daha önceki çalışmalarca da desteklenmiştir (Albayrak vd., 2007; Koçak, 2017a).

Kişilerarası engeller açısından çıkan sonuçlar daha önceki çalışmalarla kısmen paralellik göstermektedir. Daha önceki çalışmalarda kişilerarası engeller genelde arkadaş eksikliği olarak ifade edilirken (Demirel ve Harmandar, 2009; Kara ve Özdeoğlu, 2017) bu çalışmanın bulguları arasında böyle bir sonuca rastlanmamıştır. Fakat Gürbüz ve Henderson'ın (2017) çalışmasında olduğu gibi evli olan insanların bekârlara göre daha fazla engelle karşılaştığı görülmüştür. Bir spa merkezi müdürünün 'Engelleyici unsurlar genel olarak bir erkeğin, eşini kendince gerek görmediği ve katılmasını istemediği faaliyetlere göndermemesi durumudur.' ifadesinde belirttiği bu engelle özelikle kadınlar karşılaşmaktadır.

Yapısal engeller olarak daha önceki çalışmalarda vurgulanan gelir ve eğitim düzeyi ve kısıtlı zaman (Çetinkaya vd., 2018; Ekinci vd., 2014; Özşaker, 2012; Üstün vd., 2017) bu çalışmada da desteklenmiştir. Fakat bu çalışmada işletme sahipleri bakış açısı ele alındığından tesis eksikliğinin bir boş zaman engeli olduğu sonucuna varılmamıştır. Zaman eksikliği genelde evli olan kadınların veya spor kulübüne devam eden ortaokul ve lise öğrencilerinin arasında görülmektedir. STK'ların 
hizmetlerinin ücretsiz olmasından dolayı düşük gelir düzeyi katılıma engel teşkil etmemektedir. Eğitim düzeyi ise daha çok sanat merkezilerinde çalışanlar tarafından katılıma engel olarak bahsedilmiştir. Bir sanat merkezi müdürüne göre başlıca engeller 'Politika, ekonomi, öncelikler, ilgisizlik, aile, kültür ve yetiştirme tarzı başta geliyor. Bunun yanında eğitimsizlik te çok önemli bir faktör.' Ayrıca bazı işletmeciler özellikle gece yapılan aktivitelere katılımda kadınların güvenlik sorunu yaşadıklarını belirtmiştir. Türklerin karşılaştığı boş zaman engelleri Tablo 3 'te listelenmiştir.

Tablo 3

Boş Zaman Engelleri

\begin{tabular}{lll}
\hline İçsel Engeller & Kişilerarası Engeller & Yapısal Engeller \\
\hline Sedentar aktiviteleri tercih etme & Kültür ve gelenek & Gelir düzeyi \\
Motivasyon/ilgi eksikliği & Aile & Eğitim eksikliği \\
Bilinçsizlik/farkında olmama & Toplum baskısı & Güvenlik \\
Kendine güven eksikliği & & Yetersiz zaman \\
\hline
\end{tabular}

Türk toplumunda boş zaman engellerini kadınların daha çok yaşayıp yaşamadığı sorulduğunda alınan cevaplar rekreasyon işletmesinin lokasyonuna ve verdiği hizmete göre değişmektedir. Sakarya ilinde bulunan işletmelerde kadınların daha fazla engelle karşılaştığı ortaya çıkmıştır. İşletme sahiplerine göre kadınların en çok yaşadıkları engel kişilerarası engellerdir. Bir STK yöneticisi başına gelen bir olayı şöyle anlatmıştır: 'Bir teyzemizin buradaki kurslara gelip hizmet almasını istemedi eşi ve teyzemiz kursları bırakt. Gittik psikoloğumuzla beraber amcamızı bulduk oturduk konuştuk ikna ettik tekrar başladı teyzemiz kursa. İnsanlar dini açıdan bakiyorlar kültürel açıdan bakıyorlar duruma maalesef ama yavaş yavaş bu durum değişecek inşallah.' Çalışmaya katılan işletmeler arasında kadınların herhangi bir engelle karşılaşmadığını belirten hiçbir işletme bulunmamaktadır. Bir spor salonu sahibine göre: 'Her üç kadından biri kocaları tarafindan engelleniyor veya genç kızlarımız ebeveyn baskısından dolayı sporu bırakabiliyorlar. Bunun yanında çocukları olan bayanlar da zaman ve sorumluluk açsından sporu bırakabiliyorlar. Bunlar artık çok alıştığımız sorunlar. Bu tarz konularda ise erkekler çok daha rahat.' Kadınların ailevi sorumluluklarından dolayı boş zaman aktivitelerine katılamamaları Türkiye'de ve diğer ülkelerde yapılan çalışmalarca desteklenmiştir (Adam vd., 2015; Andrade vd., 2019; Brown, 2001). Ayrıca Türk kadınlarının ailevi sorumluluklara ilaveten dini ve sosyal engellerle de karşı karşıya kaldıkları daha önceki çalışmalarda olduğu gibi bu çalışmada da desteklenmiştir (Demir, 2005; Koca vd., 2009).

Rekreasyon aktivitelerine yönelik negatif düşüncelerin toplumun bazı kesimlerinde halen yer aldığ 1 bir spor salonu sahibinin şu ifadesinden anlaşılabilir: 'Kadını sokağa çıkarma çabanızı annelik ve yuva kuruculuktan uzaklaştırma faaliyetlerinizi tasvip etmiyorum. Ben bir eğitimci olarak kız çocuklarını rekreasyon ve okuma adı altında erkeklerin kucaklarına atılmasını, kişiliklerinden çıkartılmasının ve bunun adına çağdaş denilmesini kınıyorum. Kadın için bu faaliyetleri ahlak çöküntüsü olarak kabul ediyorum.' Bir STK yöneticisine göre k1sitlamalar bölgesel olarak değişiyor: 'Birebir karşılaştığım çok ciddi bir durum olmamakla birlikte; bu tür durumlar bölgesel olarak değişebiliyor. Van'da aileler klz çocuklarını göndermek istemiyordu. Genellikle evet klz çocuk yönlendirmesi sıkıntılı.' Doğu bölgelerde yaşayan kızların daha fazla engelle karşılaşmaları beklenen bir sonuçtur (Ayhan vd., 2018).

Son olarak Türklerin boş zaman aktivitelerine katılımındaki motivasyonları sorulduğunda alınan cevaplar insanların hem iç kaynaklı hem de diş kaynaklı motivasyona sahip olduklarını göstermiştir (Tablo 4). Yerlisu ve arkadaşlarının (2012) yaptığı çalışmada motivasyonun sportif faaliyetlere katılımda olumlu etkisi gözlemlenirken, sanat ve kültürel faaliyetlere katılımdaki etkisine rastlanmamıştır. $\mathrm{Bu}$ çalışmada her türlü faaliyete katılımda motivasyonun önemi işletmeciler tarafından vurgulanmıştır. Genelde spor kulüplerine katılanların başlıca motivasyonu lisans alma olarak ifade edilmiştir. Ayrıca spor kulüplerinde ve spor salonlarında antrenörlerin sporcuları motive ettikleri belirtilmiştir. Bu tarz aktivitelere katılan insanların motivasyonları genelde dış kaynaklı iken STK aktivitelerine katılım genelde iç kaynaklıdır. Yaşlılara hizmet veren bir STK yöneticisi aktivitelere katılanların günlük hayatlarında yalnız olmalarının katılımlarındaki etkisinin büyük olduğunu belirtirken, gençlere yönelik aktivite düzenleyen bir STK yöneticisi gönüllülerin topluma faydalı olmak ve bir yere ait olma isteği ile hareket ettiklerini ifade etmiştir. Diğer yandan sanat 
merkezlerine katılanlar ise daha çok eğlence, kaliteli zaman geçirme ve sosyalleşme amacı ile katılım sağlamaktadır. Açık alan rekreasyon işletmecisi ve etkinlik organizasyonu yöneticisi ise insanların faaliyetlerine katılmalarındaki amaçlarının günlük yaşamdan ve şehir hayatından uzaklaşmak olduğunu belirtmiştir.

Tablo 4

Boş Zaman Aktivitelerine Katılma Motivasyonu

\begin{tabular}{ll}
\hline İç kaynaklı & Dış kaynaklı \\
\hline Günlük hayattan uzaklaşma & Spor hocalarının çabası \\
Dinlenme ve eğlenme & Sosyal medya \\
Sağlık & Spor salonunun dizaynı \\
Ait olma & Lisans alma \\
Kilo verme/vücut geliştirme & Ödüllendirme \\
Aile ile vakit geçirme & Rekabet \\
Arkadaş edinme/sosyalleşme & \\
\hline
\end{tabular}

\section{Sonuç, Tartışma ve Öneriler}

Bu çalışmanın amacı Türk toplumundaki bireylerin boş zaman davranışlarının, boş zaman aktivitelerine katılımlarındaki motivasyonun ve yaşadıkları engellerin rekreasyon işletmeleri bakış açısından değerlendirilmesidir. Türk toplumunda boş zaman engelleri ve motivasyon üzerine yapılan çalışmaların birçoğu nicel araştırma yöntemleri ile belli bir tüketici kitlesine yönelik olarak yapılmıştır. Bu çalışma literatürdeki bu açı̆̆ 1 rekreasyon işletmecileri ile derinlemesine mülakat yapmak suretiyle kapatmayı amaçlamıştır. Ayrıca konuya rekreasyon işletmecisi bakış açısından yaklaşmak daha geniş bir müşteri kitlesinin davranışlarını incelemek açısından avantaj sağlamıştır.

Çalışma sonucunda Türklerin boş zaman aktivitelerine katılım açısından içsel, kişilerarası ve yapısal engelleri yaşadıkları desteklenmiştir (Crawford ve Godbey, 1987). Katılımcılara göre son yıllarda Türkler arasında bu tarz aktivitelere ilgi artmıştır. Fakat 'leisure' konseptinin Türkçe'ye 'boş zaman' olarak çevrilmesinden dolayı işletmeciler tarafından yanlış anlaşıldığ 1 tespit edilmiştir. Buna ek olarak işletmecilerin ifade ettiğine göre boş zaman ve rekreasyon konusunda Türk toplumunun bilgisi yetersizdir. Gelişmiş ülkelerde yapılandırılmış boş zaman aktiviteleri insanların hayatlarına küçük yaşlardan itibaren girmektedir. Ülkemizde benzer yaklaşımlar sadece bazı özel okullarda uygulanmaktadır. Türk halkının boş zamanını genel olarak pasif aktivitelerle geçirdiği işletmeciler tarfından ifade edilmiştir. İnsanların gelişim amaçlı aktiviteleri tercih etmelerini sağlamak için gelişmiş ülkelerde olduğu gibi yapılandırılmış aktivitelerin küçük yaşlarda hayatlarına girmesi gerekmektedir. $\mathrm{Bu}$ konuda okul öncesi ve ilköğretim çağındaki çocukların ve ailelerinin bilinçlendirilmesi önem arz etmektedir. Bireyler küçük yaşlardan itibaren yapılandırılmış boş zaman aktivitelerine katılmaları ileriki yaşlarda kendine güvenlerini artıracak ve bireysel engelleri aşmalarını kolaylaştıracaktır. Ayrıca insanların farkındalığını artırmak amacıyla devlet kurumları ve STK'lar tarafından üniversiteler ile işbirliği içerisinde eğitimler, çalıştaylar ve setifika programları düzenlenip, sosya medya aracılığı ile halka duyurulabilir. Türklerin yaşadığ bir diğer engel olan gelir düzeyi, devletin ve STK'ların çabaları ile aşılabilir. Günümüzde özellikle belli bir yaşın üzerinde olan insanlar iş hayatı ve ailevi sorumluluklarından dolayı boş zaman aktivitelerine yeterince vakit ayıramamaktadır. Bu noktada işyerlerinin rekreatif faaliyetler düzenlemesi ve çalışanlarının sportif, sanatsal ve kültürel aktivitelere katılımlarını desteklemesi, hem çalışanların verimlerini artırmak hem de onların gelişimlerine katkı sağlamak açsından önem teşkil etmektedir.

Kişilerarası engellerden kadınların daha fazla etkilendiği ortaya çıkmıştır. Türk toplumunun geleneksel yapısı, özellikle gelir seviyesi düşük olan kadınların boş zaman aktivitesi yapmalarına engel olmaktadır. Sakarya'da bu daha fazla hissedildiği için erkekler ve kadınlar için ayrı spor salonları bulunmaktadır. Bu uygulama kadınların sportif faaliyetlere katılımını bir nebze olsa da artırmıştır. Fakat genel anlamda bu tarz uygulamalar geçici bir çözümden öteye gitmemektedir. Kadınların boş zaman aktivitelerine sürekli katılımını sağlamak için bu tarz aktivitelerin lüksten çıkıp bir ihtiyaca dönüşmesi ve günlük hayatın bir parçası olması gerekmektedir. Türk toplumunda kadınların boş zaman aktivitelerine katılımları ile alakalı negatif görüşlerin olduğu çalışma özelinde 
desteklenmiştir. Bu kanının olumlu yönde değiştirilmesi kadınların aktivitelerine katılma konusunda daha özgür hissetmelerini sağlayacaktır. Toplum görüşünün üzerinde yoğun bir etkisi olan medya kuruluşları, eğitim kurumları ile işbirliği içerisine girerek boş zaman aktivitelerinin faydaları ile ilgili tanıtım çalışmaları düzenleyebilir.

Çalışmanın bir diğer sonucu olarak boş zaman aktivitelerine katılanların motivasyonunun içsel veya dışsal olmasının katıldıkları aktivite çeşidine bağlı olduğu söylenebilir. Bu durumda genelde dışsal motivasyonun katılıma daha fazla etkisi olduğu spor kulüpleri ve spor salonlarının pazarlama aktivitelerini bu yönde belirlemeleri daha fazla insanın düzenli spor yapmalarını sağlayacaktır. Ödül sistemi, lisans alma gibi dışsal motivasyon faktörlerinin etkisi göz önüne alınacak olursa bu tarz yöntemlerin spor salonlarında daha fazla kullanılması üyelerin daha uzun süre kalmalarını sağlayacaktır. İçsel motivasyonun daha önemli olduğu STK'lar ve sanat merkezlerinde de aynı şekilde duygusal pazarlama taktikleri ile üye sayısını artırmaya yönelik çalışmalar yapılabilir. Bireylerin boş zamanlarını aktif bir şekilde değerlendirilmesinin önemini küçük yaşlarda kavramaları, yetişkin oldukları dönemde daha fazla içsel motivasyona sahip olmalarını sağlayacaktır. Bu bağlamda okul öncesi eğitim merkezlerinde ve ilkokullarda, çocukların düzenli olarak boş zaman faaliyetlerine katılımları önem arz etmektedir. İçsel ve dışsal motivasyonu artırmak için sadece faaliyeti organize etmek yeterli olmamakla birlikte, çocukların boş zamanlarını aktif bir şekilde değerlendirmelerinin elle tutulur sonuçları olduğunu gözlemlemeleri gerekmektedir. Bunu sağlamak için gelişime yönelik sanatsal veya sportif faaliyetlere ağırlık verilebilir ve çocukların gelişimlerini ölçmek için düzenli testler yapılarak ödül sistemi geliştirilebilir.

Çalışmanın kısıtlamalarından biri sonuçların rekreasyon işletmelerinin bakış açısından değerlendirilmesidir. Elde edilen sonuçlar rekreasyon faaliyetlerine katılan insanların davranışlarını yansıtmaktadır. Gelecek çalışmalarda rekreasyon aktivitesine katılmayanlar da dahil edilerek daha kapsamlı bilgi edinilebilir. Bir diğer kısıtlama ise araştırmanın üç ille sınırlı olmasıdır. İleride yapılacak çalışmalarda Türkiye'nin değişik bölgelerinde yer alan rekreasyon işletmeleri araştırılarak sonuçlar bölge bazında incelenebilir. Çalışmada nitel araştırma yöntemleri kullanılmıştır. Gelecekte bu konu üzerinde yapılacak olan benzer çalışmalarda hem nitel hem nicel yöntemler kullanılarak daha güçlü bir analiz sunulabilir.

Türkiye'de son yıllarda boş zaman aktivitelerine olan ilginin artması topluma ekonomik ve sosyal yönden katkı sağlayacaktır. İnsanların boş zamanlarını sedentar aktivitelerle geçirmekten ziyade gelişim amaçlı kullanmaları, aile ve arkadaşları ile birlikte zaman geçirmeleri veya parkları ziyaret etmeleri bireysel mutluluğu artırarak daha iyi bir toplum olma yolunda ilerlemeye imkân verecektir. Bu konuda yapılacak akademik çalışmalar insanların boş zamanlarını daha verimli geçirmelerine teşvik edecek olan altyapıyı oluşturmak için gereken bilgiyi toplamak açısından önemlidir.

\section{Yazarların Katkı Oranı}

Çalışma tek yazarlı olduğu için yazarın katkı oranı \%100'dür.

\section{Çıkar Çatışması}

Çıkar çatışması teşkil edebilecek bir durum yoktur.

\section{Kaynaklar}

Adam, I., Hiamey, S. E. and Afenyo, E. A. (2015). Leisure constraints in the university setting in Ghana. Annals of Leisure Research, 18(1), 145-158.

Albayrak, T., Caber, M. and Crawford, D. (2007). Leisure constraints and the pursuit of adventure activities in Turkey. Anatolia, 18(2), 243-254. 
Alexandris, K., Tsorbatzoudis, C. and Grouios, G. (2002). Perceived constraints on recreational sport participation: Investigating their relationship with intrinsic motivation, extrinsic motivation and amotivation. Journal of Leisure Research, 34(3), 233-252.

Andrade, R. D., Junior, G. J. F., Capistrano, R., Beltrame, T. S., Pelegrini, A., Crawford, D. W. and Gomes Felden, É. P. (2019). Constraints to leisure-time physical activity among Brazilian workers. Annals of Leisure Research, 22(2), 202-214

Ayhan, C., Ekinci, N., Yalçın, I. and Yiğit, Ş. (2018). Investigation of constraints that occur during participation in leisure activities by high school students: A sample of Turkey. Education Sciences, 8(2), 86.

Brown, P. R., Brown, W. J., Miller, Y. D. and Hansen, V. (2001). Perceived constraints and social support for active leisure among mothers with young children. Leisure Sciences, 23(3), 131144.

Coble, T. G., Selin, S. and Erickson, B. B. (2003) Hiking alone: understanding fear, negotiation strategies and the leisure experience. Journal of Leisure Research, 35 (1), 1 - 23.

Crawford, D. W. and Godbey, G. (1987). Reconceptualizing barriers to family leisure. Leisure sciences, 9(2), 119-127.

Creswell, J.W. (2007) Qualitative Inquiry and Research Design. Choosing Among Five Approaches. Sage:CA

Crompton, J. L. and Kim, S. (2004) Temporal changes in perceived constraints to visiting state parks. Journal of Leisure Research, 36, 160.

Çetinkaya, G., Yıldız, M. and Özçelik, M. A. (2018). Why Do So Few Local People Visit National Parks? Examining Constraints to Antalya's National Parks, Turkey. Advances in Hospitality and Tourism Research (AHTR), 6(1), 92-110.

Demir, C. (2003). Impacts of demographic variables on the preference of sport activities carried out by undergraduate students: An implication from Turkey. Journal of Sport Tourism, 8(4), 302312.

Demir, C. (2005). Perceived significance of factors influencing leisure participation by gender: Implications from Turkey. Leisure/Loisir, 29(1), 121-136.

Demirel, M. ve Harmandar, D. (2009). Üniversite öğrencilerinin rekreasyonel etkinliklere katılımlarında engel oluşturabilecek faktörlerin belirlenmesi. Uluslararası Insan Bilimleri Dergisi, 6(1), 838-846.

Ekinci, N. E., Kalkavan, A., Üstün, Ü. D. ve Gündüz, B. (2014). Üniversite öğrencilerinin sportif ve sportif olmayan rekreatif etkinliklere katılmalarına engel olabilecek unsurların incelenmesi. Sportif Bakış: Spor ve Ĕ̈itim Bilimleri Dergisi, 1(1), 1-13.

Eryılmaz, S. ve Bal, H. T. (2019). Teknoloji Bağımlılı̆̆ı ile Rekreasyonel Eğilimler Arasındaki İlişki: Üniversite Öğrencileri Üzerinde Bir İnceleme, Türk Turizm Araştırmaları Dergisi, 3(4): 902919.

Erkip, F. (2009). Leisure in the Turkish context: A preliminary account. World Leisure Journal, 51(4), 275-281. 
Fedler, A. J. and Ditton, R. B. (2001). Dropping out and dropping in: A study of factors changing recreational fishing patterns. North American Journal of Fisheries Management, 21, 283 292.

Gürbüz, B. and Henderson, K. A. (2014). Leisure activity preferences and constraints: Perspectives from Turkey. World Leisure Journal, 56(4), 300-316.

Hacioglu, N., Avcikurt, C., Ilban, M. O. and Sapar, V. (2005). Leisure preferences of residents in Nevsehir, a historical city in central Turkey. World Leisure Journal, 47(3), 17-27.

Hubbard, J. and Mannell, R. C. (2001). Testing competing models of the leisure constraint negotiation process in a corporate employee recreation setting. Leisure sciences, 23(3), 145-163.

Kara, F. M. and Özdeoğlu, B. (2017). Examination of Relationship between Leisure Boredom and Leisure Constraints. Sport Sciences, 12(3), 24-36.

Kelly, J. R. and Freysinger, V.J. (2000). Leisure Play and Recreation. In $21^{s t}$ Century Leisure: Current Issues. (pp. 14-23) Boston, London, Toronto, Sydney, Tokyo, Singapore: Allyn and Bacon.

Koca, C., Henderson, K. A., Asci, F. H. and Bulgu, N. (2009). Constraints to leisure-time physical activity and negotiation strategies in Turkish women. Journal of Leisure Research, 41(2), 225251.

Koçak, F. (2017a). Leisure constraints and facilitators: Perspectives from Turkey. European Journal of Physical Education and Sport Science. 3(10). 32-47.

Kocak, F. (2017b). The relationship between leisure constraints, constraint negotiation strategies and facilitators with recreational sport activity participation of college students. College Student Journal, 51(4), 491-497.

Özşaker, M. (2012). Gençlerin serbest zaman aktivitelerine katılamama nedenleri üzerine bir inceleme. Selçuk Üniversitesi Beden Ĕ̈itimi ve Spor Bilim Dergisi, 14(1), 126-131.

Türkiye İstatistik Kurumu (2014a). İstatistiki Bölge Birimleri Sinıflamasına ve yıllara göre spor kulübü sayısl, 2007 - 2014 [Veri dosyas1]. http://www.tuik.gov.tr/VeriBilgi.do?alt_id=1087 adresinden alınmıştır (Ziyaret tarihi:10.10.2019).

Türkiye İstatistik Kurumu (2014b) [Veri dosyas1]. Ylllara göre federasyonlara bağlı lisanslı sporcu saylsl, 2007-2014 http://www.tuik.gov.tr/VeriBilgi.do?alt_id=1087 adresinden alınmıştır (Erişim tarihi:10.10.2019).

Türkiye İstatistik Kurumu (2018a) [Veri dosyas1]. Sezon yılına göre tiyatro salonu, oynanan eser ve seyirci sayısı http://www.tuik.gov.tr/PreTablo.do?alt_id=1086 adresinden alınmıştır (Erişim tarihi: 10.10.2019).

Türkiye İstatistik Kurumu (2018b) [Veri dosyas1]. Opera ve bale salonu, koltuk, oynanan eser ve seyirci saylsı http://www.tuik.gov.tr/PreTablo.do?alt_id=1086 adresinden alınmıştır (Erişim tarihi: 10.10 .2019$)$.

Türkiye İstatistik Kurumu (2018c) [Veri dosyas1]. Sinema, gösterilen film ve seyirci saylsı http://www.tuik.gov.tr/PreTablo.do?alt_id=1086 adresinden alınmıştır (Erişim tarihi: 10.10.2019). 
Turan, E. B., Gülşen, D. B. A. ve Bilaloğlu, M. (2019). Kadın Çalışanların Yaşam Doyumu İle Boş Zaman Engelleri Arasındaki İliş̧ki: Akdeniz Üniversitesi Örneği. Gaziantep Üniversitesi Spor Bilimleri Dergisi, 4(1), 104-114.

Üstun, U. D., Ersoy, A. and Bişgin, H. (2017). An Investigation on Perceived Constraints of Teachers in Relation to Leisure Activities. Turkish Journal of Sport and Exercise, 19(2), 157-161.

Yerlisu, L. T., Ağyar, E. ve Bahadır, Z. (2012). Yaşam tatmini, serbest zaman motivasyonu, serbest zaman katılımı: Beden eğitimi ve spor öğretmenleri üzerine bir inceleme (Kayseri ili örneği), Spormetre Beden Ĕgitimi ve Spor Bilimleri Dergisi, 10(2): 53-59. 


\section{Extended Abtract}

\section{Introduction}

There has been an increase in the number of recreational facilities in Turkey recently. However, participation in leisure activities is still not at a satisfactory level. According to Turkish Statistical Institute (TUIK) from 2000 to 2018 while the number of movie theaters, theaters, and opera and ballet houses has increased tremendously, the increase in number of participants in these types of activities was lower than expected (TUIK, 2018). On the other hand there is no statistical information in the number of people participating to physical leisure activities. According to Turkish Ministry of Health (2010) obesity in Turkey has reached to $20 \%$ among males, $41 \%$ among females, $\% 8.5$ among children under 5 and \%8.2 among children between 6 and 18. The main reason for obesity among Turkish people is sedentary life style. There is a need to develop leisure time activity programs to encourage Turkish people to adapt a more active lifestyle. However, in order to develop such programs, leisure constraints that Turkish people experience should be detected. A study conducted among Turkish nationals showed leisure constraints have negative influence on their life satisfaction (Turan et al., 2019). On the other hand, people who spend their leisure time more actively have higher satisfaction from life (Yerlisu, Ağyar and Bahadır, 2012). An understanding of leisure constraints among Turkish people is necessary to minimize these constraints and to increase leisure participation. Theory of leisure constraints has received attention from scholars for decades (Crawford ve Godbey, 1987). Theory assumes that people experience intrapersonal, interpersonal and structural constraints to participate in leisure activities. Previous research has shown that Turkish people experience all three types of constraints (Albayrak, Caber and Crawford, 2007; Ayhan et al., 2018; Koçak, 2017a; Üstün, Ersoy and Bişgin, 2017). Majority of studies focusing on leisure constraints in Turkey were conducted among students, therefore the representativeness is limited. Also, previous studies have analyzed leisure constraints from consumer perspective. Current study aims to analyze leisure constraints and motivation to participate leisure activities among Turkish people from the perspective of recreation facility owners and employees.

\section{Method}

Case study approach was adopted in the current study. Case study allows researchers to have an in-depth understanding of a phenomenon (Creswell, 2007). The study was conducted in three major cities in Marmara region: Istanbul, Kocaeli and Sakarya. 28 facility owners and employees were interviewed in December 2018. The recreation facilities include; 8 gyms, 5 hotel health centers, 4 sports clubs, 3 art centers, 3 Non-Governmental Organizations (NGO), 1 movie theater, 1 equestrian center, 1 yoga saloon, 1 event company and 1 outdoor recreation facility. Face to face interview technique was used. Structured interview included such questions: 'What is the percentage of women and men among your participants?', 'What are the main factors influencing the motivation of your participants?' and 'What are the major constraints that your participants experience?' Content analysis was used to analyze the results.

\section{Result, Discussion and Conclusion}

Results showed that different type of recreation facilities have different profile of participants. While people with high income and education usually prefer hotel health centers, people with low income participate in activities organized by NGOs. The long term members of sport clubs are usually under 18 and the age ranges from 18 to 40 among the members of gyms. Women have a higher tendency towards volunteer activities, while men prefer going to the movies in their free time. The results are in accordance with previous research, as according to facility owners Turkish people prefer 
sedentary activities in their free time (Ekinci vd., 2014; Erkip, 2009; Gürbüz ve Henderson, 2014; Hacıoğlu vd., 2005). With regards to leisure constraints, results revealed that Turkish people experience intrapersonal, interpersonal and structural constraints (Crawford ve Godbey, 1987). Some examples for intrapersonal constraints were low-self-confidence and lack of motivation. Similar to Gurbuz and Henderson's (2017) study, current research showed that married people experience higher constraints than single ones. Low income and lack of time were mentioned as structural constraints by facility owners. The presence of structural constraints among Turkish people was supported in previous studies as well (Çetinkaya vd., 2018; Ekinci vd., 2014; Özşaker, 2012; Üstün vd., 2017).

Study results supported the sedentary nature of Turkish people. The increase in the number of recreation facilities is not sufficient to change the life style of people. The structured leisure activities should be engrained in a person's life during childhood. At this point, the best move could be to inform and educate families on the benefits of structured leisure. Besides government, NGOs and private sector can create awareness by organizing events, seminars, workshops and certification programs. More active life style will lead to more fulfilled citizens and a better society. Therefore, academic studies focusing on leisure activity participation is important. This study has attempted to fill this gap by interviewing recreation facility owners and employee's. It is recommended that future studies investigate this subject from the perspective of participants and non-participants. 